\title{
Intake of fruits, vegetables, folic acid and related nutrients and risk of breast cancer in postmenopausal women
}

\author{
Barbara Thorand', Lenore Kohlmeier ${ }^{1,2 *}$, Naal Simonsen ', Carry Croghan' and \\ Michael Thamm ${ }^{3}$ \\ 'Department of Epidemiology, School of Public Health, McGavran-Greenberg Hall, CB\#7400, \\ University of North Carolina at Chapel Hill, Chapel Hill, NC 27599-7400, USA: ${ }^{2}$ Department of \\ Nutrition, Schools of Public Health and Medicine, McGavran-Greenberg Hall, CB\#7400, University of \\ North Carolina at Chapel Hill, Chapel Hill, NC 27599-7400, USA: ${ }^{3}$ Robert Koch Institute, General- \\ Pape-Strasse 62-66, D.12101 Berlin, Germany
}

\section{Submitted 21 May 1998: Accepted 12 July 1998}

\begin{abstract}
Objective: To determine the role of fruit and vegetable consumption and dietary intake of folic acid and related nutrients such as methionine, cysteine and alcohol in the aetiology of breast cancer.

Design: Population based case-control study.

Setting: Part of the European Community Multicentre Study on Antioxidants, Myocardial Infarction, and Cancer of the Breast (EURAMIC) in Berlin, Germany.

Subjects: As part of the EURAMIC study, dietary intake data were collected in 43 postmenopausal women diagnosed with breast cancer between 1991 and 1992 in Berlin, Germany, and compared to 106 population-based controls.

Results: Odds ratios (ORs) adjusted for major risk factors of breast cancer but not for total energy intake showed a non-significant inverse association between a high intake of vegetables $(\mathrm{OR}=0.76,95 \% \mathrm{CI}=0.48-1.20)$ and fruits $(\mathrm{OR}=0.74,95 \%$ $\mathrm{CI}=0.48-1.15)$ and breast cancer. Once results were adjusted for total energy intake the associations became much weaker (vegetables: $\mathrm{OR}=0.86,95 \% \mathrm{CI}=0.51-1.46$; fruits: $O R=0.82,95 \% \mathrm{CI}=0.51-1.32$ ). For all nutrients, the effect of energy adjustment was more profound and the inverse associations disappeared when results were adjusted for energy intake (total folate-not energy adjusted: $\mathrm{OR}=0.79$, 95\% $\mathrm{CI}=0.51-1.21$; energy adjusted: $\mathrm{OR}=1.14,95 \% \mathrm{CI}=0.73-1.79$; folate equivalents-not energy adjusted: $\mathrm{OR}=0.81,95 \% \mathrm{CI}=0.53-1.23$; energy adjusted: $\mathrm{OR}=1.16,95 \% \mathrm{CI}=0.78-1.74$; methionine-not energy adjusted: $\mathrm{OR}=0.60,95 \%$ $\mathrm{CI}=0.35-1.03$; energy adjusted: $\mathrm{OR}=1.29,95 \% \mathrm{CI}=0.76-2.19$; cysteine-not energy adjusted: $\mathrm{OR}=0.52,95 \% \mathrm{CI}=0.29-0.94$; energy adjusted: $\mathrm{OR}=1.22,95 \%$ $\mathrm{CI}=0.75-1.97$ ). Alcohol intake was inversely associated with breast cancer in a nonsignificant way, possibly due to the relatively low alcohol intake of the study population. Conclusions: The results of this study do not provide firm evidence that a high intake of fruits and vegetables, folic acid, methionine or cysteine reduces the risk of getting breast cancer.
\end{abstract}

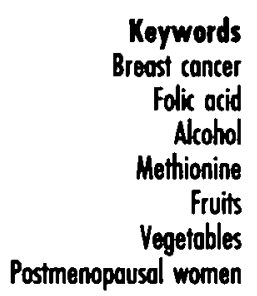

Keywords

Font concer

Alcohol

Athionine

Fruits

Postmenopausal women
Breast cancer is the most prevalent cancer in women and the second leading cause of cancer deaths in women ${ }^{1}$. A positive family history is one of the few established risk factors for the disease, however, a lot of controversies exist concerning other major risk factors. Considering the large differences observed in breast cancer incidence rates worldwide ${ }^{2}$ and changes in the incidence among populations migrating from low- to high-incidence areas, it has been postulated that dietary habits may play an important role in the aetiology of the disease $^{3}$. While a lot of attention has previously been given to the role of dietary fat and alcohol intake ${ }^{4}$, recent research suggests that vegetable and fruit consumption may be even more important $t^{5}$. However, the factors which are responsible for the protective effect of a diet high in fruits and vegetables are still mainly unknown.

There is some evidence that high carotenoid intake $^{6-10}$ or high intake of antioxidant vitamins $s^{5,7,11}$ is associated with a reduced risk of breast cancer, but study results have not always been consistent $^{6,9,10,12-22}$ and other constituents of fruits and vegetables may be important as well. Fruits and vegetables are major sources of folic acid in the diet and thus folic acid could be one of the constituents which is responsible for the inverse association 
observed between intake of vegetables and fruits and risk of breast cancer.

A role for folic acid in cancer aetiology is supported by its biological functions. Folic acid is required for the biosynthesis of purines and needed for the methylation of uridylate to thymidylate. Thus, inadequate folic acid availability can disrupt nucleotide synthesis and may cause DNA damage. Folic acid is also important for DNA methylation and abnormal methylation may affect gene regulation $^{23}$. Therefore, it was the aim of this study to observe whether folic acid and other nutrients which affect methyl-group availability in the diet such as alcohol and methionine are associated with breast cancer and whether an inverse association between folic acid and breast cancer could explain any protective effect observed for high intakes of fruits and vegetables.

\section{Subjects and methods}

\section{Study population}

Data were collected in conjunction with a larger casecontrol study on risk factors for postmenopausal breast cancer conducted in five European centres (EURAMIC - European Community Multicentre Study on Antioxidants, Myocardial Infarction, and Cancer of the Breast). For a detailed description of the study design see Kardinaal et $a^{24}{ }^{24}$. Included in this report are postmenopausal women (no periods during the past 24 months), aged 38-80 living in East and West Berlin. Written, informed consent was obtained from all women and the study protocol was approved by the ethics committee of the Federal Health Office (BGA).

Cases of incident breast cancer (International Classification of Diseases (ICD) code 174) were recruited in the surgical units of three major hospitals in Berlin in 1991-1992. Breast cancers had to be histologically classified as ductal carcinoma, with primary tumours less than $5 \mathrm{~cm}$, axillary lymph node stage $<\mathrm{N} 3$ and no clinical indication of distant metastases at discharge. Further inclusion criteria for cases and controls were: no changes in the use of dietary supplements containing $\alpha$-tocopherol, $\beta$-carotene and selenium; no new or altered dietary prescription by the general practitioner in the past year (except for prescribed changes to energy-restricted or low-sodium diets); no weight loss over $5 \mathrm{~kg}$ in the past year; no history of treatment for alcohol or drug abuse; and no major psychiatric disorders or institutionalization. Controls were selected at random, frequency matched by age according to 5year intervals, from registry lists representing the areas of draw for the cases. Selected controls were first contacted by a short letter followed by a telephone call to make an appointment for a visit at the study centre. The response rate (i.e. number of eligible subjects interviewed divided by the number of invited persons) was $75 \%$ for the cases and $45 \%$ for the controls.

\section{Data collection}

Self-administered questionnaires were used to collect information on weight, height, smoking habits, alcohol intake, socioeconomic status, family history of breast cancer (defined as having at least one first-degree relative (mother, sister, daughter) with breast cancer), and reproductive history including age at menarche, age at pregnancy, parity, use of oral contraceptives, use of supplemental hormones and age at menopause.

In addition, diet during the previous year was assessed using an interviewer administered automated diet history which prompted questions about habitual diet meal by meal. The programme has been validated against long-term dietary intakes using 7-day dietary records in a German population. The reproducibility of the method measured on 47 individuals, 17-73 years of age was found to be good. The unadjusted correlation coefficients were generally between 0.6 and 0.7 and energy adjustment generally strengthened the results. The data set created from the diet history programme included information on the frequency of consumption of 201 food items (open list) and the amount typically consumed when the food was eaten by subject identification number. Dietary intake data were available for 43 cases and 108 controls.

\section{Food intake and nutrient composition data}

Total fruit and vegetable intake was calculated by multiplying the amount typically consumed with the frequency of consumption of a specific food. Then total consumed amounts of all foods of a specific group such as fruits or vegetables were summed to give the total amount of fruit and vegetable consumption per person. Prepared dishes that contained mainly vegetables, such as vegetable salads, were included in the vegetable category. Mixed dishes that contained only small amounts of vegetables (e.g. pasta with tomato sauce, pizza or soups) were not included in the total vegetable consumption variables. Two variables were created for total vegetable consumption, one including potatoes and potato dishes, the other excluding them.

Nutrient composition of foods was derived from the German Federal Food Code (BLS) nutrient database (version II.2). This database was developed by the Federal Health Office and is maintained by the Robert Koch Institute using nutrient composition data of German foods if available. Data on the folate content of various food items was updated using data recently obtained at the German Institute of Nutrition Research ${ }^{25-28}$. For processed foods (e.g. canned vegetables, fruit juices), folate composition values were imputed from unprocessed foods using a factor derived from the original database to account for 
nutrient losses during food processing. Folate intake is reported as total folate intake and as folate equivalent intake. Folate equivalents take into account the different bioavailability of folate monoglutamate and folate polyglutamate forms and are calculated as follows: folate equivalent intake $=$ folate monoglutamate intake $+0.2 \times$ folate polyglutamate intake.

\section{Statistical analysis}

Relative risks of breast cancer were estimated with odds ratios (ORs) and $95 \%$ CIs comparing the difference in risk associated with a unit change corresponding to a move from 25th to 75 th percentile of nutrient intake. Percentiles were calculated using data from cases and controls combined. ORs were calculated with unconditional logistic regression. To assess the potential for confounding, adjusted ORs were calculated using multiple logistic regression. The following variables were included in the models since they were the most important predictors of breast cancer risk in this data set: age, body mass index (BMI), age at menarche, nulliparity (yes/no), smoking status (current smoker, ex-smoker and never smoker coded as two indicator variables), exogenous hormone use (yes/no) and socioeconomic status (SES) coded as two indicator variables. Age at menopause, age at pregnancy and family history of breast cancer (i.e. diagnosis of breast cancer in mother, sister or daughter) (yes/no) did not predict breast cancer and were, therefore, not included in the final adjusted model. Because folate, methionine and cysteine intakes were highly correlated with energy intake, energy adjusted nutrient intakes were calculated using residuals from a linear regression of the nutrient on total energy intake after both had been transformed into logarithms ${ }^{29}$. To obtain meaningful units the antilogarithm of the residuals was taken after the mean of the logarithmic nutrient intake had been added to the residuals. All ORs are reported for energy adjusted and unadjusted nutrient intakes. In addition to using the continuous nutrient intake variables, tertiles of unadjusted and energy adjusted nutrient intakes were created and models were run using two indicator variables to describe the tertiles of nutrient intake. Since the obtained results were not materially different from the results using the continuous variables, only the continuous analysis is shown here.

\section{Results}

Altogether 49 breast cancer cases and 109 controls were included in the study. Since dietary information was missing for six cases and one control and information for some covariates was not available for two control subjects, ORs are generally reported for 43 cases and 106 controls to be able to compare crude and adjusted ORs.
Table 1 Medians and ranges of relevant variables describing the study population

\begin{tabular}{|c|c|c|c|}
\hline Variable & $\begin{array}{l}\text { Controls } \\
(n=106)\end{array}$ & $\begin{array}{l}\text { Cases } \\
(n=43)\end{array}$ & $P$-value \\
\hline Age & $\begin{array}{c}58 \\
(39-74)\end{array}$ & $\begin{array}{c}62 \\
(39-81)\end{array}$ & 0.05 \\
\hline BMI & $\begin{array}{c}25 \\
(18-38)\end{array}$ & $\begin{array}{c}26 \\
(18-38)\end{array}$ & 0.04 \\
\hline Weight (kg) & $\begin{array}{c}67 \\
(45-110)\end{array}$ & $\begin{array}{c}70 \\
(46-102)\end{array}$ & 0.12 \\
\hline Height (cm) & $\begin{array}{c}164 \\
(143-176)\end{array}$ & $\begin{array}{c}163 \\
(152-178)\end{array}$ & 0.62 \\
\hline Age at menarche & $\begin{array}{c}14 \\
(11-18)\end{array}$ & $\begin{array}{c}14 \\
(11-18)\end{array}$ & 0.12 \\
\hline Age at menopause $e^{\ddagger}$ & $\begin{array}{c}48 \\
(28-55)\end{array}$ & $\begin{array}{c}48 \\
(28-55)\end{array}$ & 1.00 \\
\hline $\begin{array}{l}\% \text { current smoker } \\
\% \text { ex-smoker }\end{array}$ & $\begin{array}{l}18 \\
29\end{array}$ & $\begin{array}{l}14 \\
44\end{array}$ & $\begin{array}{l}0.56 \\
0.08\end{array}$ \\
\hline$\%$ low SES & 15 & 19 & $0.20^{\dagger}$ \\
\hline $\begin{array}{l}\% \text { medium SES } \\
\% \text { high SES }\end{array}$ & $\begin{array}{l}63 \\
22\end{array}$ & $\begin{array}{r}72 \\
9\end{array}$ & \\
\hline $\begin{array}{l}\text { Family history of breast cancer } \\
(\%)\end{array}$ & 8 & 5 & 0.52 \\
\hline Exogenous hormone use (\%) & 70 & 51 & 0.03 \\
\hline Nulliparity (\%) & 24 & 21 & 0.73 \\
\hline
\end{tabular}

Table 1 shows the distribution of breast cancer cases and controls by age, BMI, weight, height, age at menarche, age at menopause, smoking status, SES, family history of breast cancer, exogenous hormone use (either oral contraceptive use or oestrogen replacement therapy) and nulliparity.

Table 2 describes the median and ranges for the dietary intake variables of interest in this study by casecontrol status of the subjects. Total caloric intake was the only variable which differed significantly between cases and controls. The median intake for the cases was $1797 \mathrm{kcal} \mathrm{day}^{-1}$ while it was $1973 \mathrm{kcal} \mathrm{day}^{-1}$ for the controls. Total fruit and vegetable intake as well as folate, methionine, cysteine and alcohol intake all tended to be lower in cases than in controls but none of these differences reached statistical significance. These tendencies may have resulted from the fact that food and nutrient intakes were highly correlated with energy intake (Table 3).

Table 4 shows the results for the relationship between breast cancer risk and fruit and vegetable intake modelled as a continuous variable. When total fruit and vegetable intake was not adjusted for total energy intake a higher intake seemed to be moderately protective for breast cancer although none of the ORs reached statistical significance. After adjustment for total energy intake the protective trend was much weaker.

Vegetables and fruits were the major sources of folate in the diet. An average of $37 \%$ of total folate intake was supplied by vegetables and $20 \%$ by fruits. Grain products and cereals contributed $24 \%$ of total folate 
Table 2 Medians and ranges of relevant variables describing food and nutrient intakes

\begin{tabular}{|c|c|c|c|}
\hline Variable & $\begin{array}{l}\text { Controls } \\
(n=106)\end{array}$ & $\begin{array}{c}\text { Cases } \\
(n=43)\end{array}$ & $P$-value ${ }^{*}$ \\
\hline Total fruit intake $\left(\mathrm{g}\right.$ day $\left.{ }^{-1}\right)$ & $\begin{array}{c}244 \\
(0-904)\end{array}$ & $\begin{array}{c}225 \\
(0-948)\end{array}$ & 0.51 \\
\hline Total vegetable intake $\left(\mathrm{g} \mathrm{day}^{-1}\right)$ & $\begin{array}{c}313 \\
(13-1624)\end{array}$ & $\begin{array}{c}288 \\
(21-996)\end{array}$ & 0.69 \\
\hline Total vegetable and potato intake $\left(\mathrm{g}\right.$ day $\left.^{-1}\right)$ & $\begin{array}{c}441 \\
(44-1665)\end{array}$ & $\begin{array}{c}388 \\
(104-1102)\end{array}$ & 0.38 \\
\hline Total calories (kcal day ${ }^{-1}$ ) & $\begin{array}{c}1973 \\
(814-4026)\end{array}$ & $\begin{array}{c}1797 \\
(1189-2679)\end{array}$ & 0.02 \\
\hline Total calories $\left(\mathrm{kJ}\right.$ day $\left.^{-1}\right)$ & $\begin{array}{c}8255 \\
(3406-16845)\end{array}$ & $\begin{array}{c}7519 \\
(4975-11,209)\end{array}$ & 0.02 \\
\hline Total folate intake $\left(\mu \mathrm{g} \mathrm{day}^{-1}\right)$ & $\begin{array}{c}213 \\
(68-553)\end{array}$ & $\begin{array}{c}203 \\
(125-656)\end{array}$ & 0.46 \\
\hline Folate equivalents intake $\left(\mu \mathrm{g}\right.$ day $\left.^{-1}\right)$ & $\begin{array}{c}135 \\
(47-408)\end{array}$ & $\begin{array}{c}126 \\
(77-418)\end{array}$ & 0.27 \\
\hline Methionine intake $\left(\mathrm{mg} \mathrm{day}^{-1}\right)$ & $\begin{array}{c}1559 \\
(688-3860)\end{array}$ & $\begin{array}{c}1496 \\
(823-2309)\end{array}$ & 0.19 \\
\hline Cysteine intake $\left(\mathrm{mg} \mathrm{day}^{-1}\right)$ & $\begin{array}{c}960 \\
(423-2050)\end{array}$ & $\begin{array}{c}860 \\
(529-1248)\end{array}$ & 0.11 \\
\hline Alcohol intake ( day $\left.^{-1}\right)$ & $\begin{array}{c}2.3 \\
(0-123.1)\end{array}$ & $\begin{array}{c}1.7 \\
(0-17.1)\end{array}$ & 0.24 \\
\hline
\end{tabular}

-Wilcoxon-Mann-Whitney test.

intake. Respective percentages for intake of folate equivalents were $30 \%, 19 \%$ and $27 \%$ for vegetables, fruits and grain products. Methionine was supplied by a variety of different food sources. The most important ones were meat $(42 \%)$, milk products $(19 \%)$, grain products and cereals (14\%), fish (8\%) and vegetables (7\%). Cysteine was also supplied by a number of different foods such as meat (34\%), grain products and cereals $(28 \%)$, milk products $(12 \%)$, vegetables $(7 \%)$ and eggs (6\%).

Table 5 shows the ORs for the association of energy, folate, methionine, cysteine and alcohol intake with breast cancer. Total caloric intake was negatively associated with breast cancer risk (OR $=0.50,95 \%$ $\mathrm{CI}=0.29-0.85$ ). Total folate, folate equivalents, methionine and cysteine intakes also showed negative association with breast cancer when they were not adjusted for total energy intake but only the OR for cysteine reached statistical significance. Adjustment for total energy intake removed all signs of an inverse association with breast cancer for each of these nutrients. The association between alcohol intake and breast cancer risk was negative but not statistically significant. Since alcohol intake was not correlated with energy intake, energy adjusted intakes have not been calculated.

Since folate and methionine intake both influence methyl-group availability, categories were created to represent diets with a low, intermediate and high methyl-group availability. A high folate and high methionine diet was inversely associated with breast cancer $(\mathrm{OR}=0.43,95 \% \mathrm{CI}=0.17-1.11$ using total folate; $\mathrm{OR}=0.40,95 \% \mathrm{CI}=0.16-1.03$ using folate equivalents). When dietary intakes were adjusted for total energy intake, however, the inverse association disappeared and a diet high in folate and methionine

Table 3 Pearson correlation coefficients between nutrient and food intake variables

\begin{tabular}{|c|c|c|c|c|c|c|c|c|c|}
\hline & $\begin{array}{l}\text { Total energy } \\
\text { intake }\end{array}$ & $\begin{array}{l}\text { Total fruit } \\
\text { intake }\end{array}$ & $\begin{array}{c}\text { Total } \\
\text { vegetable } \\
\text { intake }\end{array}$ & $\begin{array}{c}\text { Total } \\
\text { vegetable } \\
\text { and potato } \\
\text { intake }\end{array}$ & $\begin{array}{l}\text { Total folate } \\
\text { intake }\end{array}$ & $\begin{array}{l}\text { Folate } \\
\text { equivalents } \\
\text { intake }\end{array}$ & $\begin{array}{l}\text { Methionine } \\
\text { intake }\end{array}$ & $\begin{array}{c}\text { Cysteine } \\
\text { intake }\end{array}$ & $\begin{array}{l}\text { Alcohol } \\
\text { intake }\end{array}$ \\
\hline Total energy intake & 1.00 & & & & & & & & \\
\hline Total fruit intake & 0.26 & 1.00 & & & & & & & \\
\hline Total vegetable intake & 0.34 & 0.89 & 1.00 & & & & & & \\
\hline $\begin{array}{l}\text { Total vegetable and } \\
\text { potato intake }\end{array}$ & 0.44 & 0.86 & 0.96 & 1.00 & & & & & \\
\hline Total folate intake & 0.58 & 0.37 & 0.58 & 0.61 & 1.00 & & & & \\
\hline Folate equivalents intake & ke 0.57 & 0.34 & 0.54 & 0.56 & 0.97 & 1.00 & & & \\
\hline Methionine intake & 0.81 & 0.19 & 0.30 & 0.38 & 0.58 & 0.56 & 1.00 & & \\
\hline Cysteine intake & 0.89 & 0.14 & 0.24 & 0.33 & 0.56 & 0.56 & 0.94 & 1.00 & \\
\hline Alcohol intake & 0.15 & -0.05 & -0.03 & -0.02 & -0.02 & 0.04 & 0.02 & 0.02 & 1.00 \\
\hline
\end{tabular}


Table 4 OR for the association of nutrient intakes with breast cancer* (comparison of 75 th versus 25 th percentile of intake) ${ }^{\dagger}$

\begin{tabular}{lcc}
\hline Variable & $\begin{array}{c}\text { Crude OR } \\
(95 \% \mathrm{Cl})\end{array}$ & $\begin{array}{c}\text { Adjusted OR } \\
(95 \% \mathrm{Cl})\end{array}$ \\
\hline $\begin{array}{l}\text { Not energy adjusted food intakes } \\
\text { Total fruit intake }\end{array}$ & 0.85 & 0.74 \\
& $(0.58-1.26)$ & $(0.48-1.15)$ \\
Total vegetable intake & 0.87 & 0.76 \\
Total vegetable intake including potatoes & $(0.59-1.29)$ & $(0.48-1.20)$ \\
Energy adjusted food intakes & 0.82 & 0.72 \\
Total fruit intake & $(0.54-1.24)$ & $(0.45-1.15)$ \\
Total vegetable intake & 0.97 & 0.82 \\
Total vegetable intake including potatoes & $(0.63-1.49)$ & $(0.51-1.32)$ \\
& 1.03 & 0.86 \\
\hline
\end{tabular}

cases $n=43$, controls $n=106$.

$\uparrow$ Percentile intake values: total fruit intake ( $g$ day $\left.{ }^{-1}\right) 75$ th: 336,25 th: 145 ; total vegetable intake $\left(g\right.$ day $\left.{ }^{-1}\right)$ 75th: 438, 25th: 198; total vegetable intake including potatoes $\left(\mathrm{g}\right.$ day $\left.{ }^{-1}\right) 75$ th: 554,25 th: 290 ; total energy adjusted fruit intake $\left(\mathrm{g} \mathrm{day}^{-1}\right)$ 75th: 352,25 th: 146 ; total energy adjusted vegetable intake ( $\mathrm{g}$ day $\left.{ }^{-1}\right) 75$ th: 467, 25th: 207; total energy adjusted vegetable intake including potatoes ( $g$ day $^{-1}$ ) 75 th: 563,25 th: 305 . ‡ Adjusted for age, BMI, exogenous hormone use, age at menarche, nulliparity, smoking status (current smoker, ex-smoker), SES.

showed a moderate though not statistically significant positive association with breast cancer $(\mathrm{OR}=1.20,95 \%$ $\mathrm{CI}=0.44-3.22$, using total folate; $\mathrm{OR}=1.11,95 \%$ $\mathrm{CI}=0.40-3.09$, using folate equivalents) (Table 6).

\section{Discussion}

In this study, total fruit and vegetable consumption as well as intakes of folic acid, methionine and cysteine

Table 5 OR for the association of nutrient intakes with breast cancer* (comparison of 75 th versus 25 th percentile of intake $)^{\dagger}$

\begin{tabular}{lcc}
\hline Variable & $\begin{array}{c}\text { Crude OR } \\
(95 \% \mathrm{Cl})\end{array}$ & $\begin{array}{c}\text { Adjusted OR } \\
(95 \% \mathrm{Cl})\end{array}$ \\
\hline Total calories & 0.56 & 0.50 \\
$(0.35-0.91)$ & $(0.29-0.85)$
\end{tabular}

Not energy adjusted nutrient intakes Total folate intake

0.88

Folate equivalents intake

Methionine intake

Cysteine intake

Alcohol intake

Energy adjusted nutrient intakes

Total folate intake

Folate equivalents intake

Methionine intake

Cysteine intake

\begin{tabular}{cc}
0.88 & 0.79 \\
$(0.60-1.31)$ & $(0.51-1.21)$ \\
0.88 & 0.81 \\
$(0.60-1.29)$ & $(0.53-1.23)$ \\
0.67 & 0.60 \\
$(0.41-1.10)$ & $(0.35-1.03)$ \\
0.59 & 0.52 \\
$(0.34-1.02)$ & $(0.29-0.94)$ \\
0.72 & 0.81 \\
$(0.46-1.12)$ & $(0.53-1.24)$ \\
& \\
1.24 & \\
$(0.82-1.86)$ & $(0.73-1.79)$ \\
1.21 & 1.16 \\
$(0.83-1.76)$ & $(0.78-1.74)$ \\
1.22 & 1.29 \\
$(0.77-1.94)$ & $(0.76-2.19)$ \\
1.15 & 1.22 \\
$(0.76-1.74)$ & $(0.75-1.97)$ \\
\hline
\end{tabular}

- cases $n=43$, controls $n=106$

† Percentile intake values: energy intake ( $\left.\mathrm{kcal} \mathrm{day}^{-1}\right)$ 75th: 2220, 25th: 1560; total folate $\left(\mu \mathrm{g} \mathrm{day}{ }^{-1}\right) 75$ th: 271, 25th: 170; folate equivalents $\left(\mu \mathrm{g} \mathrm{day}^{-1}\right)$ 75th: 174, 25th: 105; methionine (mg day $\left.{ }^{-1}\right) 75$ th: 1901 , 25th: 1241; cysteine $\left(\mathrm{mg} \mathrm{day}^{-1}\right)$ 75th: 1118, 25th: 733; alcohol $\left(\mathrm{g} \mathrm{day}^{-1}\right)$ 75th: 5.1, 25th: 0.1; energy adjusted total folate $\left(\mu \mathrm{g}\right.$ day $\left.^{-1}\right)$ 75th: 262,25 th: 182 ; energy adjusted folate equivalents $\left(\mu \mathrm{g}^{-1 a y}{ }^{-1}\right) 75$ th: $^{-1}$ 168. 25th: 117; energy adjusted methionine ( $\left.\mathrm{mg} \mathrm{day}^{-1}\right)$ 75th: 1727, 25th:1367; energy adjusted cysteine (mg day ${ }^{-1}$ ) 75 th: 985,25 th: 844

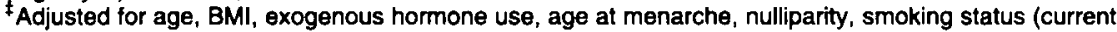
smoker, ex-smoker), SES. 
Table 6 OR for the association of folic acid and methionine intakes with breast cancer

\begin{tabular}{|c|c|c|c|c|c|}
\hline Not energy adjusted & $\begin{array}{l}\text { (reference category) } \\
\text { Low total folate and } \\
\text { low methionine }\end{array}$ & $\begin{array}{l}\text { Low total folate and } \\
\text { high methionine }\end{array}$ & $\begin{array}{l}\text { High total folate and } \\
\text { low methionine }\end{array}$ & $\begin{array}{l}\text { High total folate and } \\
\text { high methionine }\end{array}$ & $\begin{array}{l}\text { Test for trend } \\
\text { p-value }\end{array}$ \\
\hline $\begin{array}{l}\text { No. of cases/no. of controls } \\
\text { Crude OR }(95 \% \mathrm{Cl})\end{array}$ & $\begin{array}{c}18 / 37 \\
1.0\end{array}$ & $\begin{array}{c}7 / 13 \\
1.11 \\
(0.38-3.25)\end{array}$ & $\begin{array}{c}6 / 14 \\
0.88 \\
(0.29-2.67)\end{array}$ & $\begin{array}{c}12 / 42 \\
0.59 \\
(0.25-1.38)\end{array}$ & 0.21 \\
\hline \multirow[t]{2}{*}{ Adjusted ORß $(95 \% \mathrm{Cl})$} & 1.0 & $\begin{array}{c}1.24 \\
(0.38-4.05)\end{array}$ & $\begin{array}{c}0.58 \\
(0.17-2.00)\end{array}$ & $\begin{array}{c}0.43 \\
(0.17-1.11)\end{array}$ & 0.06 \\
\hline & $\begin{array}{l}\text { low folate } \\
\text { equivalents and } \\
\text { low methionine }\end{array}$ & $\begin{array}{c}\text { low folate } \\
\text { equivalents and } \\
\text { high methionine }\end{array}$ & $\begin{array}{l}\text { high folate } \\
\text { equivalents and } \\
\text { low methionine }\end{array}$ & $\begin{array}{l}\text { high folate equivalents } \\
\text { equivalents and } \\
\text { high methionine }\end{array}$ & \\
\hline $\begin{array}{l}\text { No. of cases/no. of controls } \\
\text { Crude OR }(95 \% \mathrm{Cl})\end{array}$ & $\begin{array}{c}19 / 36 \\
1.0\end{array}$ & $\begin{array}{c}7 / 13 \\
1.02 \\
(0.35-2.99)\end{array}$ & $\begin{array}{c}5 / 15 \\
0.63 \\
(0.20-2.00)\end{array}$ & $\begin{array}{c}12 / 42 \\
0.54 \\
(0.23-1.27)\end{array}$ & 0.13 \\
\hline Adjusted OR§ $(95 \% \mathrm{Cl})$ & 1.0 & $\begin{array}{c}1.05 \\
(0.32-3.40)\end{array}$ & $\begin{array}{c}0.40 \\
(0.11-1.44)\end{array}$ & $\begin{array}{c}0.40 \\
(0.16-1.03)\end{array}$ & 0.04 \\
\hline
\end{tabular}

Energy adjusted

(reference category)

low e.a." total folate and low e.a. total folate high e.a. total folate high e.a. total folate

low e.a. methionine high e.a. methionine low e.a. methionine high e.a. methionine

\begin{tabular}{|c|c|c|c|c|c|}
\hline & & & & \multirow{3}{*}{$\begin{array}{c}16 / 30 \\
1.44 \\
(0.59-3.55) \\
1.20 \\
(0.44-3.22)\end{array}$} & \\
\hline $\begin{array}{l}\text { No. of cases } / \mathrm{no} \text {. of controls } \\
\text { Crude OR }(95 \% \mathrm{Cl})\end{array}$ & $\begin{array}{c}13 / 34 \\
1.0\end{array}$ & $\begin{array}{c}8 / 20 \\
1.12 \\
(0.39-3.24)\end{array}$ & \multirow{2}{*}{$\begin{array}{c}6 / 22 \\
0.68 \\
(0.22-2.11) \\
0.58 \\
(0.17-1.97)\end{array}$} & & 0.55 \\
\hline Adjusted OR§ $(95 \% \mathrm{CI})$ & 1.0 & $\begin{array}{c}1.27 \\
(0.39-4.11)\end{array}$ & & & 0.96 \\
\hline & $\begin{array}{l}\text { low e.a. folate } \\
\text { equivalents } \\
\text { and low e.a. } \\
\text { methionine }\end{array}$ & $\begin{array}{l}\text { low e.a. folate } \\
\text { equivalents } \\
\text { and high e.a. } \\
\text { methionine }\end{array}$ & $\begin{array}{l}\text { high e.a. folate } \\
\text { equivalents } \\
\text { and low e.a. } \\
\text { methionine }\end{array}$ & $\begin{array}{l}\text { high e.a. folate } \\
\text { equivalents } \\
\text { and high e.a. } \\
\text { methionine }\end{array}$ & \\
\hline $\begin{array}{l}\text { No. of cases/no. of controls } \\
\text { Crude OR }(95 \% \mathrm{Cl})\end{array}$ & $\begin{array}{c}13 / 30 \\
1.0\end{array}$ & $\begin{array}{c}9 / 23 \\
0.95 \\
(0.34-2.67)\end{array}$ & $\begin{array}{c}6 / 26 \\
0.53 \\
(0.17-1.64)\end{array}$ & $\begin{array}{c}15 / 27 \\
1.38 \\
(0.55-3.49)\end{array}$ & 0.68 \\
\hline Adjusted OR§ $(95 \% \mathrm{Cl})$ & 1.0 & $\begin{array}{c}1.06 \\
(0.34-3.31)\end{array}$ & $\begin{array}{c}0.45 \\
(0.13-1.51)\end{array}$ & $\begin{array}{c}1.11 \\
(0.40-3.09)\end{array}$ & 0.87 \\
\hline
\end{tabular}

e.a.: energy adjusted.

$\S$ Adjusted for age, BMI, exogenous hormone use, age at menarche, childbirth, smoking status (current smoker, ex-smoker), SES

Low nutrient intake category refers to nutrient intake below or equal to the median intake, high nutrient intake category refers to intake above the median; median values are: total folate $\left(207 \mu \mathrm{g}\right.$ day $\left.^{-1}\right)$, folate equivalents $\left(132 \mu \mathrm{g}\right.$ day $\left.^{-1}\right)$, methionine $\left(1529\right.$ mg day $\left.^{-1}\right)$, energy adjusted total folate $\left(223 \mu \mathrm{g}\right.$ day $\left.{ }^{-1}\right)$, energy adjusted folate equivalents $\left(138 \mu \mathrm{g}\right.$ day $\left.^{-1}\right)$, energy adjusted methionine (1504 $\left.\mathrm{mg} \mathrm{day}^{-1}\right)$.

were negatively associated with breast cancer, however, once results were adjusted for total energy intake the association disappeared in most cases or became much weaker. Thus, the central question for the interpretation of the results is whether or not it is necessary or appropriate to adjust for total energy intake. In this context, the reasons for the observed difference in total energy intake between cases and controls need to be considered first. In the absence of methodological errors, four main factors are generally associated with total energy intake: body size, metabolic efficiency, net energy balance and physical activity $^{30}$. In this study, cases had a higher BMI and were slightly heavier than controls but the absolute differences were small and probably did not reflect considerable differences in energy intake. Furthermore, any confounding effect of BMI should have been in the opposite direction than the observed difference.
Subjects were excluded from participation in the study if they had lost more than $5 \mathrm{~kg}$ in the past year, thus substantial weight loss in the case group could not account for the observed difference, however, controls could have gained weight during the past year. Since weight gain is associated with an increased risk for breast cancer in postmenopausal women ${ }^{31}$ it would be more likely, however, that cases gained weight. Therefore, this factor is unlikely to explain the lower energy intake of the cases. Since we do not have any data on the metabolic efficiency and epidemiological studies generally do not assess this factor it is impossible to evaluate its importance. Physical activity seems to be the most important explanation for between-person differences in energy intake ${ }^{30}$. We do not have any information on the physical activity level of cases and controls in this study, but there is some evidence in the literature that reduced physical activity 
is associated with an increased risk for breast cancer $^{32-36}$. Therefore, different physical activity levels between cases and controls could (partially) explain the observed difference in energy intake. In addition, methodological errors such as recall bias or selection bias could have influenced the reported energy intake.

If the observed differences in energy intake reflect true differences or if the cases generally underreported their intake of all foods and if, in addition, not the absolute nutrient intake but rather the composition of the diet is important, it would be appropriate to adjust for total energy intake in the analysis. If the case group, however, selectively underreported their intake of fat and/or alcohol, which are major contributors to caloric intake, adjustment for energy intake would lead to a distortion of the association between disease and other foods and nutrients such as fruits, vegetables, folic acid and methionine, because mistakes in the assessment of fat or alcohol would be carried over by energy adjustment to the foods and nutrients of primary interest. Since it is impossible to identify the source of the observed differences in energy intake between cases and controls with certainty, it is unclear whether energy adjusted or unadjusted analyses are more appropriate. Results from both analyses are, therefore, reported here. This example shows the importance of considering the implications of total energy intake in the analysis of nutrient-disease relationships. This is often not done in nutritional epidemiological studies. Studies which use a food frequency questionnaire with a limited amount of food items to assess dietary intake are often especially unable to derive an accurate measure of total caloric intake. Differences in dietary assessment methodology and ways in which total energy intake is taken into account may, therefore, explain some of the different results concerning consumption of fruits and vegetables and related nutrients such as vitamins and fibre and risk of breast cancer.

A number of studies observed that a high intake of vegetables is associated with a reduced risk of breast cancer ${ }^{5,9,15.37-40}$ but an approximately equal number of studies did not find such a relationship ${ }^{12.16-19,22,41.42}$. The association between a high intake of fruits and risk of breast cancer has generally been weaker and only borderline significant in many studies $5,9,15,37,42$ and various studies did not observe any association between intake of fruits and risk of breast cancer $^{10,16,18,22,38}$ or a tendency for an increased risk of breast cancer at high intakes of certain fruits ${ }^{19}$. The same mixed results have been obtained for vitamins whose intake is associated with fruit and vegetable consumption. Some researchers found a protective effect for carotenoids ${ }^{6-10}$, vitamin $A^{12,22,43}$, vitamin $C^{5,7}$ and vitamin $E^{5,7,21}$ while others did not find any effect of carotenoids ${ }^{13,16-19,21,44}$, vitamin $A^{0,9,14-16,18-21}$, vitamin $C^{9,10,12,16.18,22}$ and vitamin $E^{10,16.19,22,44}$. Study results for the effect of dietary fibre on breast cancer risk have also been mixed. Some studies either observed a direct inverse association between fibre intake and breast cancer risk or found that intake of grain and cereal products was negatively associated with breast cancer risk $5,15,40,44-46$. However, other investigators did not observe any association ${ }^{18,20.37 .43}$ or study results were inconclusive $e^{7,9,10.38}$.

Since vegetables, fruits and foods high in fibre such as grain products also contain large amounts of folic acid, we postulated that folic acid might be one of the specific components of these foods contributing to the protective effect. So far, only two studies have examined the effect of folic acid intake on breast cancer risk. Graham et $\mathrm{al}^{7}{ }^{7}$ observed an inverse association between folic acid intake and breast cancer in postmenopausal women, but the effect was confined to the highest quartile of folate intake (not energy adjusted: $\mathrm{OR}=0.70,95 \% \quad \mathrm{CI}=0.48-1.02$ ); energy adjusted: $O R=0.72,95 \% \quad C I=0.46-1.12$ ). Freudenheim et $a l^{5}$ reported a strong inverse association for folic acid from foods in premenopausal women $(\mathrm{OR}=0.50,95 \% \mathrm{CI}=0.31-0.82$ for highest quartile of intake; adjusted for various covariates and energy intake), but no association for folic acid from supplements.

Considerable biochemical evidence supports a role of folic acid and related nutrients in the aetiology of cancer. DNA methylation abnormalities seem to be early stages in the neoplastic process. Gene expression is regulated by DNA methylation patterns and there is some evidence that hypomethylation of proto-oncogenes may contribute to their increased expression ${ }^{47-50}$ while hypermethylation of tumour-suppressor genes can lead to their inactivation ${ }^{50-59}$. Therefore, one possible mechanism of how folic acid and other nutrients which affect methyl-group availability, such as vitamin $\mathrm{B}_{12}$, methionine, choline and alcohol, could affect carcinogenesis is their potential impact on patterns of DNA methylation ${ }^{58,60-63}$.

Several other mechanisms may explain a role of folic acid in oncogenesis. Folic acid deficiency can lead to misincorporation of uracil into DNA and may promote the in situ formation of uracil in DNA through deamination of cytosine. Such substitutions interfere with the normal interaction between DNA and the proteins that maintain the condensed structure of the chromosomes, leading to decondensed chromosomes which may be more susceptible to DNA damage ${ }^{49.64}$. Though nearly all cells have repair mechanisms which remove uracil from DNA, higher repair rates increase the rate of double-strand DNA breaks. This in turn leads to a greater chance of translocations, deletions, rearrangements and duplications which can activate 
proto-oncogenes or inactivate tumour-suppressor genes and thereby promote carcinogenesis ${ }^{64}$. Severe folate deficiency might also suppress the ability of natural killer cells to destroy dysplastic or cancerous cells $^{49}$.

Since alcohol may affect the metabolism of folic acid $^{65}$ and has previously been associated with the risk of breast cancer ${ }^{66}$ we were particularly interested in assessing a combined effect of folic acid and alcohol intake. Our hypothesis was that women with a low folic acid and a high alcohol intake would have the highest risk of breast cancer. However, we did not see such an effect (data not shown). This may have been due to the low alcohol intake in this group of postmenopausal women. The median intake was only $2.3 \mathrm{~g} \mathrm{day}^{-1}$ in the controls and $1.7 \mathrm{~g} \mathrm{day}^{-1}$ in the cases. An alcohol intake above $12 \mathrm{~g} \mathrm{day}^{-1}$, which is approximately equivalent to 1 drink day ${ }^{-1}$, was reported by only $9.4 \%$ of all women and only $0.7 \%$ reported an intake above $30 \mathrm{~g} \mathrm{day}^{-1}$. Various studies have shown different results concerning the effect of moderate intakes of alcohol. In his meta-analyis of 38 epidemiological studies on alcohol consumption and risk of breast cancer, Longnecker ${ }^{67}$ observed a dose-response relationship and calculated a relative risk (RR) of 1.10 for an alcohol intake of $13 \mathrm{~g}$ $\mathrm{day}^{-1}$ ( 1 drink day ${ }^{-1}$ ). However, Howe et al. ${ }^{68}$ found no association between breast cancer risk and alcohol consumption below $40 \mathrm{~g} \mathrm{day}^{-1}$, while the risk for those who consumed $\geq 40 \mathrm{~g} \mathrm{day}^{-1}$ was considerably increased compared to non-drinkers $(R R=1.69,95 \%$ $\mathrm{CI}=1.19-2.40)$. In The Netherlands cohort study ${ }^{69}$ a considerable increase in risk was also only seen at intakes of $30 \mathrm{~g}$ or more per day. Thus, the level of alcohol consumption in our study population may have been too low to observe any significant alcohol effect.

Since the metabolism of methionine is also tightly connected to the metabolism of folic acid, we also assessed the association of methionine intake with risk of breast cancer and examined the interaction between folic acid and methionine intake. To our knowledge the role of methionine in the aetiology of breast cancer has not been assessed in previous studies. However, various studies examined the effect of protein intake. Overall, there is no strong evidence for an association between protein intake and breast cancer risk ${ }^{45}$, but it may be possible that certain types of protein or specific foods rich in protein are associated with breast cancer risk. Animal protein intake was found to be positively associated with breast cancer risk ${ }^{16}$ and a few studies observed an increased risk of breast cancer at high meat intakes $9,18,38,70$.

We focused on the role of folic acid, methionine and alcohol in the aetiology of breast cancer and did not consider vitamin $B_{12}$ or choline in spite of their involvement in methyl-group availability due to the following reasons: in reasonably well-nourished elderly populations vitamin $\mathrm{B}_{12}$ status mainly depends on vitamin $B_{12}$ absorption and not on vitamin $B_{12}$ intake $^{71}$ and thus the dietary intake data available in this study would not be very informative. It seems unlikely that cases and controls differed in their ability to absorb vitamin $B_{12}$, but we cannot totally exclude that a difference in vitamin $B_{12}$ status and its effect on folate metabolism could have influenced the results of this study. Choline was not considered because it is widespread in the food supply and the normal human diet seems to provide sufficient choline ${ }^{72}$.

A number of potential confounding factors such as age, BMI, family history of breast cancer, exogenous hormone use, age at menarche, age at menopause, nulliparity, smoking, SES and total energy intake were considered in the analysis. On the whole adjustment for these potential confounders - apart from total energy intake - did not have a significant effect on the observed associations between nutrient intake and breast cancer risk. Thus, it seems unlikely that other potential confounders would have had a large effect, although we cannot be absolutely sure about this. We did not have any information on levels of physical activity. Total energy intake could be a surrogate for physical activity and therefore, adjustment for total energy intake may have taken this factor into account, but this remains speculative. Furthermore, no information on use of folic acid containing supplements was available. Since use of vitamin supplements was not very common in Germany at the time when the study was conducted, however, this probably did not lead to a considerable distortion of the results.

One other issue deserves further consideration. In this study, we assessed only diet during the previous year although exposure during earlier time periods may have been more relevant. If folic acid or other components of fruits and vegetables have an effect on cancer initiation the relevant time of exposure may have been about 20-30 years ago. If these nutrients, however, affect tumour promoters or inhibitors, exposure during the more recent years could have been important. Assessment of dietary habits in the distant past has several methodological problems and often use of current diet may be a reasonable surrogate for past dietary habits, however, profound dietary changes in the studied population could lead to a distortion of the observed effect ${ }^{30}$.

In conclusion, this study does not provide convincing evidence for an inverse association between a diet high in fruits, vegetables, folic acid, methionine or cysteine and risk of breast cancer. However, such an association can also not be excluded. Several issues complicate the interpretation of the study results, the most important one being the large difference in energy intake between cases and controls. Since there is convincing biochemical evidence for a role of folic acid 
- and possibly related nutrients - in oncogenesis, future studies which have a larger study population and also assess physical activity levels should address the role of these nutrients in the aetiology of breast cancer.

\section{Acknowledgements}

The EURAMIC study was supported as a Concerted Action by the Commission of European Communities (DG-XII and DG-V). The national studies were financed by the Ulster Cancer Foundation and Milk Intervention Board (Co-responsibility Levy Disbursement, Reg (EEC) 1001/90 Contract 77.2), Dutch Ministry of Health, Spanish FIS and Ministry of Science and Education, German Federal Health Office, Cancer Research Switzerland (AKT76), and Swiss NSF (329257-87). These analyses were sponsored in part by the US Department of the Army (grant DAMD17-94-J4200). Barbara Thorand was supported by the German Academic Exchange Service (DAAD).

EURAMIC coordinating centre participants in this study: Robert Koch Institute, Berlin, Germany (L Kohlmeier PhD, M Thamm MSc); University of North Carolina, Chapel Hill, USA (L Kohlmeier PhD, N Simonsen $\mathrm{PhD}$ ).

\section{References}

1 American Cancer Society Inc. Cancer Facts and Figures 1995. Atlanta: American Cancer Society Inc., 1995; Part A; 10-11.

2 Cancer incidence in five continents. In: Parkin DM, Muir CS, Whelan SL, Gao YT, Ferlay J, Powell J, eds. LARC Scientific Publications no. 120. vol. VI. Lyon: International Agency for Research on Cancer, 1992.

3 Hunter DJ, Willett WC. Nutrition and breast cancer. Cancer Causes and Control 1996; 7: 56-68.

4 Hankin JH. Role of nutrition in women's health: diet and breast cancer. J. Am. Dietet. Assoc. 1993; 93: 994-9.

5 Freudenheim JL, Marshall JR, Vena JE, et al. Premenopausal breast cancer risk and intake of vegetables, fruits, and related nutrients. J. Nat. Cancer Inst. 1996; 88: 340-8.

6 Potischman N, McCulloch CE, Byers T, et al. Breast cancer and dietary and plasma concentrations of carotenoids and vitamin A. Am. J. Clin. Nutr. 1990; 52: 909-15.

7 Graham S, Hellmann R, Marshall J, et al. Nutritional epidemiology of postmenopausal breast cancer in Western New York. Am. J. Epidemiol. 1991; 134: 552-66.

8 Lee HP, Gourley L, Duffy SW, Esteve J, Lee J, Day NE. Dietary effects on breast-cancer risk in Singapore. Lancet 1991; 337 1197-2000.

9 Levi F, La Vecchia C, Gulie C, Negri E. Dietary factors and breast cancer risk in Vaud, Switzerland. Nutrition and Cancer 1993; 19: 327-35

10 Holmberg L., Ohlander EM, Byers T, et al. Diet and breast cancer risk. Results from a population-based, case-control study in Sweden. Arch. Int. Med. 1994; 154: 1805-11

11 Paganini-Hill A, Chao A, Ross RK, Henderson BE. Vitamin A, beta-carotene, and the risk of cancer: a prospective study. $J$. Nat. Cancer Inst. 1987; 79: 443-8.

12 Graham S, Marshall J, Mettlin C, Rzepka T, Nemoto T, Byers T. Diet in the epidemiology of breast cancer. Am. J. Epidemiol. 1982; 116: 68-75.
13 Marubini E, Decarli A, Costa A, et al. The relationship of dietary intake and serum levels of retinol and beta-carotene with breast cancer. Results of a case-control study. Cancer 1988; 61: 173-80.

14 Rohan TE, McMichael AJ, Baghurst PA. A population-based case-control study of diet and breast cancer in Australia. Am. J. Epidemiol. 1988; 128: 478-89.

15 Iscovich JM, Iscovich RB, Howe G, Shiboski S, Kaldor JM. A case-control study of diet and breast cancer in Argentina. Int. J. Cancer 1989; 44: 770-6.

16 Toniolo P, Riboli E, Protta F, Charrel M, Cappa APM. Calorie providing nutrients and risk of breast cancer. J. Nat. Cancer Inst. 1989; 81: 278-86.

17 Ewertz M, Gill C. Dietary factors and breast-cancer risk in Denmark. Int. J. Cancer 1990; 46: 779-84.

18 Ingram DM, Nottage $\mathrm{E}$, Roberts $\mathrm{T}$. The role of diet in the development of breast cancer: a case-control study of patients with breast cancer, benign epithelial hyperplasia and fibrocystic disease of the breast. Br.J. Cancer 1991; 64 : 187-91.

19 Richardson S, Gerber M, Cenée S. The role of fat, animal protein and some vitamin consumption in breast cancer: a case-control study in southern France. Int. J. Cancer 1991; 48: $1-9$.

20 Graham S, Zielezny M, Marshall J, et al. Diet in the epidemiology of postmenopausal breast cancer in the New York State Cohort. Am. J. Epidemiol. 1992; 136: 1327-37.

21 London SJ, Stein EA, Henderson IG, et al. Carotenoids, retinol, and vitamin $\mathrm{E}$ and risk of proliferative benign breast disease and breast cancer. Cancer Causes and Control 1992; 3: $503-12$

22 Hunter DJ, Manson JE. Colditz GA, et al. A prospective study of the intake of vitamins $\mathrm{C}, \mathrm{E}$, and $\mathrm{A}$ and the risk of breast cancer. New' Engl. J. Med. 1993; 329: 234́-40.

23 Laird PW. Oncogenic mechanisms mediated by DNA methylation. Molecular Med. Today 1997; 3: 223-29.

24 Kardinaal AF, van't Veer P, Kok FJ, et al. EURAMIC study: antioxidants, myocardial infarction and breast cancer. Design and main hypotheses. Eur. J. Clin. Nutr. 1993; 47: S64-S72.

25 Müller H. Bestimmung der Folsäure-Gehalte von Getreide, Getreideprodukten, Backwaren und Hülsenfrüchten mit Hilfe der Hochleistungsflüssigkeitschromatographie (HPLC). Z. Lebensmitteluntersuch. Forsch. 1993; 197: 573-7.

26 Müller H. Bestimmung der Folsäure-Gehalte von Gemüse und Obst mit Hilfe der Hochleistungsflüssigkeitschromatographie (HPLC). Z. Lebensmitteluntersuch. Forsch. 1993; 196: $137-41$.

27 Müller H. Die Folsäure-Aufnahme mit der täglichen Gesamtnahrung-Einfluss der Speisenzubereitung auf deren Folsäure-Gehalt. Z. Lebensmitteluntersuch. Forsch. 1995; 200: 209-12

28 Müller H. Neubestimmung und Bewertung der Folsäuregehalte von ausgewählten Lebensmitteln pflanzlicher und tierischer Herkunft. Ernäbrungs-Umscbau 1995; 42: 170-4.

29 Willett W, Stampfer MJ. Total energy intake: implications for epidemiologic analyis. Am. J. Epidemiol. 1986; 124: 17-27.

30 Willett W. Nutritional Epidemiology. New York: Oxford University Press, 1990.

31 Ziegler RG. Anthropometry and breast cancer. J. Nutr. 1997; 127: 924S-8S.

32 Bernstein L, Henderson BE, Hanisch R, Sullivan-Halley J, Ross RK. Physical exercise activity reduces the risk of breast cancer in young women. J. Nat. Cancer Inst. 1994; 86: 1403-8.

33 Friedenreich $\mathrm{CM}$, Rohan TE. Physical activity and risk of breast cancer. Eur. J. Cancer Prev. 1995; 4: 145-51.

34 D'Avanzo B, Nanni O, La Vecchia C, et al. Physical activity and breast cancer risk. Cancer Epidemiol. Biomarkers Prev. 1996; 5: 155-60.

35 Coogan PF, Newcomb PA, Clapp RW, Trentham-Dietz A, 
Baron IA, Longnecker MP. Physical activity in usual occupation and risk of breast cancer (United States) Cancer Causes and Control 1997; 8: 626-31.

36 Thune I, Brenn T, Lund E, Gaard M. Physical activity and the risk of breast cancer. New Engl. J. Med. 1997; 336: 1269-75.

37 Katsouyanni K, Trichopoulos D, Boyle P, Xirouchaki E, Trichopoulou A, Lisseos B. Diet and breast cancer: a casecontrol study in Greece. Int. J. Cancer 1986; 38: 815-20.

38 La Vecchia C, Decarli A, Franceschi S, Gentile A, Negri E, Parazzini F. Dietary factors and the risk of breast cancer. Nutr. and Cancer 1987; 10: 205-14.

39 Pawlega $J$. Breast cancer and smoking, vodka drinking and dietary habits. A case-control study. Acta Oncol. 1992; 31: 387-92.

40 Rohan TE, Howe GR, Friedenreich $\mathrm{CM}$, Jain M, Miller AB. Dietary fiber, vitamins $A, C$, and $E$, and risk of breast cancer: a cohort study. Cancer Causes and Control 1993; 4: 29-37.

41 Hislop TG, Coldman AJ, Elwood JM, Brauer G, Kan L. Childhood and recent eating patterns and risk of breast cancer. Cancer Detection and Prevention 1986; 9: 47-58.

42 van't Veer $P$, Kolb $C M$, Verhoef $P$, et al. Dietary fiber, betacarotene and breast cancer: results from a case-control study. Int. J. Cancer 1990; 45: 825-8

43 Katsouyanni K, Willett W, Trichopoulos D, et al. Risk of breast cancer among Greek women in relation to nutrient intake. Cancer 1988; 61: 181-5.

44 van 't Veer P, Strain JJ, Fernandez-Crehuet J, et al. Tissue antioxidants and postmenopausal breast cancer: the European Community Multicentre Study on Antioxidants, Myocardial Infarction, and Cancer of the Breast (EURAMIC). Cancer Epidemiol. Biomarkers Prev. 1996; 5: 441-7.

45 Howe GR, Hirohata T; Hislop TG, et al. Dietary factors and risk of breast cancer: combined analysis of 12 case-control studies. J. Nat. Cancer Inst. 1990; 82: 561-9.

46 Zaridze D, Lifanova Y, Maximovitch D, Day NE, Duffy SW. Diet, alcohol consumption and reproductive factors in a case-control study of breast cancer in Moscow. Int. J. Cancer 1991; 48: 493-501.

47 Feinberg A, Vogelstein B. Hypomethylation of ras oncogenes in primary human cancers. Biochem. Biophys. Res. Comm. 1983; 111: 47-54.

48 Counts JL, Goodman Jl. Hypomethylation of DNA: a nongenotoxic mechanism involved in tumor promotion. Toxicol. Lett. 1995; 82-83: 663-72.

49 Mason JB. Folate status: effects on carcinogenesis. In: Bailey LB, ed. Folate in Health and Disease. New York: Marcel Dekker, 1995: 361-77.

50 Gonzalgo ML, Jones PA. Mutagenic and epigenetic effects of DNA methylation. Mutation Res. 1997; 386: 107-18.

51 Baylin SB, Makos M, We J, Chiu Yen RW, de Bustros A Abnormal patterns of DNA methylation in human neoplasia potential consequences for tumor progression. Cancer Cells 1991; 3: 382-90

52 Issa J-P J, Ortaviano L, Celano P, Hamilton SR, Davidson NE, Baylin SB. Methylation of the oestrogen receptor CPG island links ageing and neoplasia in human colon. Nature Genet. 1994; 7: 536-40.
53 Laird PW, Jaenisch R. DNA methylation and cancer. Hum. Mol. Genet. 1994; 3: 1487-95.

54 Balmain A. Cancer exploring the bowels of DNA methylation. Curr. Biol. 1995; 5: 1013-16

55 Bird AP. The relationship of DNA methylation to cancer Cancer Sun: 1996; 28: 87-101.

56 Jones PA. DNA methylation errors and cancer. Cancer Res. 1996; 56: 2463-7.

57 Laird PW, Jaenisch $\mathbf{R}$. The role of DNA methylation in cancer genetic and epigenetics. Ann. Rev. Genet. 1996; 30: 441-64.

58 Zingg JM, Jones PA. Genetic and epigenetic aspects of DNA methylation on genome expression, evolution, mutation and carcinogenesis. Carcinogenesis 1997; 18: 869-82.

59 Jones PA, Gonzalgo ML. Altered DNA methylation and genome instability: a new pathway to cancer? Proc. Nat. Acad. Sci. USA 1997; 94: 2103-5.

60 Hoffman RM. Altered methionine metabolism, DNA methylation and oncogene expression in carcinogenesis. Biochim. Biophys. Acta 1984; 738 : 49-87.

61 Eto I, Krumdieck CL. Role of vitamin $B_{12}$ and folate deficiencies in carcinogenesis. Adv. Exp. Med. Biol. 1986 206: 313-30.

62 Balaghi $M$, Wagner $C$. DNA methylation in folate deficiency: use of CPG methylase. Biochem. Biophys. Res. Comm. 1993; 193: $1184-90$.

63 Jennings E. Folic acid as a cancer-preventing agent. Med Hypoth. 1995; 45: 297-303.

64 Blount BC, Ames BN. DNA damage in folate deficiency Baillière's Clin. Haematol. 1995; 8: 461-78.

65 Halsted $\mathrm{CH}$. Alcohol and folate intereactions: clinical implications. In: Bailey LB, ed. Folate in Health and Disease New York: Marcel Dekker, 1995: 313-27.

66 Jensen OM, Paine SL, McMichael AJ, Ewertz M. Alcohol. In: Schottenfeld D, Fraumeni JF, eds. Cancer Epidemiology and Prevention, 2nd edn. Oxford: Oxford University Press, 1996: 290-318.

67 Longnecker MP. Alcoholic beverage consumption in relation to risk of breast cancer: meta-analyis and review. Cancer Causes and Control 1994; 5: 73-82.

68 Howe G, Rohan T, Decarli A, et al. The association between alcohol and breast cancer risk: evidence from the combined analysis of six dietary case-control studies. Int. J. Cancer 1991; 47: 707-10.

69 van den Brandt PA, Goldbohm RA, van 't Veer P. Alcohol and breast cancer: results from The Netherlands Cohort Study. Am. J. Epidemiol. 1995; 141: 907-15.

70 Hislop TG, Kan L, Coldman AJ, Band PR, Brauer G. Influence of estrogen receptor status on dietary risk factors for breast cancer. Canad. Med. Assoc. J. 1988; 138: 424-30.

71 Herbert V, Das KC. Folic acid and vitamin $B_{12}$. In: Shils ME, Olson JA, Shike M, eds. Modern Nutrition in Health and Disease. Philadelphia: Lea \& Febiger, 1994: 402-25.

72 Zeisel SH, Blusztain JK. Choline and human nutrition. Ann Rev. Nutr. 1994; 14: 269-96. 